\title{
German council confounds plans for neutron project
}

\section{Quirin Schiermeier, Munich}

Plans for a major neutron source to be built in Europe suffered a significant setback last week, when Germany's science council declined to endorse the project.

The European Spallation Source (ESS) was one of nine proposed science projects assessed by the council in a report published on 12 July. But the neutron source received an unexpectedly harsh review, which has now raised doubts over whether Germany will provide its share of the funds needed for the project.

The council endorsed an assessment of the ESS by a subcommittee chaired by Hans Spiess, a director at the Max Planck Institute for Polymer Research in Mainz, saying that the demand for neutrons does not justify the estimated 1.4-billion-euro (US\$1.4-billion) total investment in an advanced neutron source. By 2011, the earliest date that the ESS could become operational, some of its studies could be done more cheaply using alternative technologies such as synchrotrons or electron microscopes, the council said in its statement.

Instead it argued that higher priority should be given to TESLA, an electronpositron collider proposed for construction at DESY, the high-energy physics research centre in Hamburg. TESLA, which is expected to cost 3.5 billion euros, will also feature a 670-million-euro X-ray free-electron laser, which will produce high-energy pulses that can be used to determine the structure of biological molecules, among other things (see Nature 415, 110-111;2002).

"The ESS would allow continuation of neutron research, if on a very high level," explains Spiess. "But TESLA is a truly visionary project that will open completely new ground."

The council's assessment has shocked European neutron scientists, who had hoped that construction of the ESS could start at a site in Europe by 2004. The facility would be used to probe the molecular structure of matter. Structural biologists, condensedmatter physicists and geologists, for example,

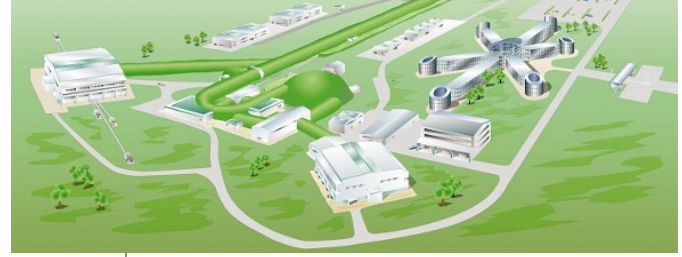

Cool response: plans for a European neutron source have failed to win approval in Germany.

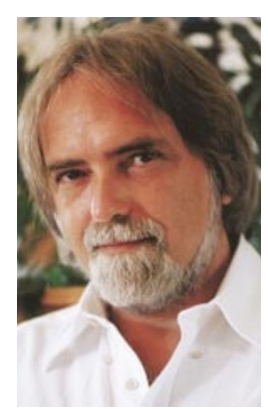

Bob Cywinski says

Europe needs a new neutron source. favour neutron sources because they can identify lighter atoms such as hydrogen in structures.

"It is nonsense to play off synchrotrons or free-electron lasers against neutrons. They are complementary leaps into the future," says Bob Cywinski, a physicist at the University of Leeds, and former chairman of the European Neutron Scattering Association. "If you take away Europe's leading edge in neutron research you take away our leadership in condensedmatter science as well," he adds.

Japan and the United States are already building neutron sources that are expected to come on line in 2006. With the ESS which is a partnership between Germany, France, Britain and other European nations - researchers were hoping to retain their traditional leadership in neutron science (see Nature 417, 883; 2002).

Two sites in Germany — the Research Centre Jülich in North Rhine Westphalia and a greenfield site in Saxony-Anhalt have put in a bid to host the facility. But they need to redesign and streamline their applications, Spiess says, before the council will support them.

It is still possible that Germany will eventually host the ESS, officials say, or at least contribute to the project's costs if it is built elsewhere. But without a positive vote from its influential science council, the German government is unlikely to back the project.

At the very least, the council's verdict is expected to complicate informal negotiations between the countries involved in the project, which is still at an early stage. Britain, for example, has not yet even offered a candidate site for the neutron source.

Peter Tindemans, chairman of the ESS research council, said in a letter to Germany's science council, the Wissenschaftsrat, and to the science ministers of Saxony-Anhalt and North Rhine Westphalia that the German science council's assessment was not widely shared, and that a "European consensus view" would determine the project's future.

Tindemans says he thinks that the decision will delay the ESS, but not necessarily kill it. "The last word has not yet been spoken," he says, "but without a firm commitment from Germany, it will be extremely difficult to get the project off the ground.”

\section{Senate nod prompts fresh analysis of nuclear waste dump}

\section{Geoff Brumfiel, Washington}

The US Senate's decision on 9 July to approve the proposed nuclear-waste repository at Yucca Mountain, Nevada, has set the stage for a fresh and exhaustive technical investigation of the plan.

The Department of Energy (DOE), which is running the project, must produce convincing data on hundreds of technical issues before starting to build the repository, in 2008 at the earliest.

The Nuclear Regulatory Commission (NRC), which must grant a licence before the project can begin, has a list of 293 separate topics that it wants answers on, officials there say. There remain "gaps in information" concerning the site's volcanic and seismic activity, hydrology and geology, as well as engineering issues, says Janet Schlueter, a branch chief at the NRC's Division of Waste Management.

Under the terms of the licence application, project managers have to satisfy the NRC that the repository will contain the waste safely for 10,000 years. And Schlueter stresses that the licensing process will not be a simple 'rubber stamp' - the NRC has a four-year window to interrogate the DOE over the proposal.

Energy undersecretary Robert Card says that the project team has collected data that will fulfil most of the NRC's requirements. "We've already resolved many of these issues," he says. The department hopes to file its application by the end of 2004 .

But "there are several issues where there is significant work to be done", says George Hornberger, an environmental scientist at the University of Virginia and chairman of the NRC's Advisory Committee on Nuclear Waste. NRC officials have recently raised the possibility of volcanism at the site, says Hornberger. Both the DOE and the NRC are currently running computer simulations to address a disagreement about the risk posed by volcanic activity (see Nature 412, 850-852; 2001).

Other questions surround the deterioration of the sophisticated metal containers that would hold the waste, says Kevin Crowley, director of the Board on Radioactive Waste Management at the National Research Council. Project planners "need to understand how that metal will behave over thousands of years", he says.

Hornberger is not convinced that the DOE will be able to complete its licence application by 2004. "They have a lot to do, and it's not going to be easy," he says. 